\title{
Sonic Hedgehog Signaling Pathway in Endothelial Progenitor Cell Biology for Vascular Medicine
}

\author{
Amankeldi A. Salybekov ${ }^{1}$, Ainur K. Salybekova ${ }^{1}$, Roberto Pola ${ }^{2}$ (i) and Takayuki Asahara ${ }^{1, *}$ \\ 1 Department of Regenerative Medicine Science, Tokai University School of Medicine, 143 Shimokasuya, \\ Isehara, Kanagawa 2591193, Japan; amansaab0@gmail.com (A.A.S.); ainurasaab@gmail.com (A.K.S.) \\ 2 Department of Medicine, Fondazione Policlinico Universitario A. Gemelli IRCCS, Università Cattolica del \\ Sacro Cuore, 00168 Rome, Italy; roberto.pola@unicatt.it \\ * Correspondence: asa777@is.icc.u-tokai.ac.jp
}

Received: 15 September 2018; Accepted: 1 October 2018; Published: 5 October 2018

\begin{abstract}
The Hedgehog $(\mathrm{HH})$ signaling pathway plays an important role in embryonic and postnatal vascular development and in maintaining the homeostasis of organs. Under physiological conditions, Sonic Hedgehog $(\mathrm{SHH})$, a secreted protein belonging to the $\mathrm{HH}$ family, regulates endothelial cell growth, promotes cell migration and stimulates the formation of new blood vessels. The present review highlights recent advances made in the field of SHH signaling in endothelial progenitor cells (EPCs). The canonical and non-canonical SHH signaling pathways in EPCs and endothelial cells (ECs) related to homeostasis, $\mathrm{SHH}$ signal transmission by extracellular vesicles (EVs) or exosomes containing single-strand non-coding miRNAs and impaired SHH signaling in cardiovascular diseases are discussed. As a promising therapeutic tool, the possibility of using the SHH signaling pathway for the activation of EPCs in patients suffering from cardiovascular diseases is further explored.
\end{abstract}

Keywords: sonic hedgehog; endothelial cells; endothelial progenitor cells; canonical signaling; non-canonical signals; extracellular vesicles

\section{Introduction}

Endothelial progenitor cells (EPCs) were first isolated from adult peripheral blood (PB) in 1997 [1]. Circulating EPCs are bone marrow (BM)-derived cells that incorporate into the foci of physiological or pathological neovascularization to form new blood vessels [2]. In situ, circulating EPCs localize at sites of neovascularization and differentiate into endothelial cells (ECs). This process is similar to vasculogenesis, which involves the formation of new blood vessels during embryonic development. In adult organisms, a reservoir of EPCs from bone marrow contributes to postnatal neovascularization [3]. The discovery of EPCs has expanded the field of vascular biology beyond the conventional EC biology and now is applied for studies involving organ regeneration and vascular diseases. Several research investigations related to regenerative medicine have aimed at elucidating the differentiation cascade of EPCs and their role in the origin of vascular development. Two types of EPCs have been described, namely, hematopoietic including circulating EPCs and non-hematopoietic EPCs. Few non-hematopoietic EPCs include endothelial out-growth cells (EOCs) and tissue resident c-kit+/CD45- progenitor cells $[2,4,5]$. Several signaling cascades are common to hematopoietic EPCs, non-hematopoietic EPCs and differentiated ECs. However, distinct signaling mechanisms associated with the differentiation and subsequent bioactivity of EPCs reveals their unique role in vascular development and pathology during the postnatal period.

The Hedgehog $(\mathrm{HH})$ signaling pathway coordinates embryonic and postnatal angiogenesis as well as organogenesis. In vertebrates, during the early embryonic development, $\mathrm{HH}$ morphogens play a crucial role in the development of organs such as limbs [6,7], neurons (axon elongation and astrocyte 
development) [8-10] and cardiac and vascular structures for septal cardiogenesis, angiogenesis and vasculogenesis [11-15]. Mammals have three genes with homology to the Hh gene, namely, Sonic hedgehog (SHH), Indian hedgehog (IHH) and Desert hedgehog (DHH). The SHH signaling pathway has drawn research interest as it induces postnatal vasculogenesis under homeostasis and pathological conditions [16-20].

The present review focuses on the recent research developments in EPC biology, namely, (i) canonical and non-canonical SHH signaling pathways in EPCs and EC, related to homeostasis, (ii) $\mathrm{SHH}$ signal transmission by extracellular vesicles such as exosomes containing single-strand non-coding miRNAs and (iii) impaired SHH signaling in cardiovascular diseases. In conclusion, the role of activated SHH signaling pathway in EPCs as a promising therapeutic tool for cardiovascular patients has been explored.

\subsection{SHH Signaling Pathways in Vascular Development}

Classical canonical SHH signaling is initiated by the binding of SHH morphogens to 12-pass transmembrane cell surface receptor Patched 1 (PTCH 1) present on the target cell [21]. De-repressed smoothened (SMO) protein, a central signal transducer of the SHH signaling pathway, activates the downstream glioma-associated oncogene homolog (GLI) family of transcription factors, namely, GLI1, GLI2 and GLI3 (Figure 1). Direct binding of suppressor of fused (SUFU) to GLI transcription factors negatively regulates GLI-mediated transcription by inhibiting their nuclear entry and ability to transcribe DNA [22]. At the nuclear level, accumulation of GLI transcription factors activate target genes associated with proliferation (Cyclin-D1, MYC), apoptosis (BCL-2), angiogenesis (ANG)1/2, PDGF-BB, VEGF)), epithelial-to-mesenchymal transition (SNAIL) and stem cell self-renewal (NANOG, SOX2) $[21,23,24]$.

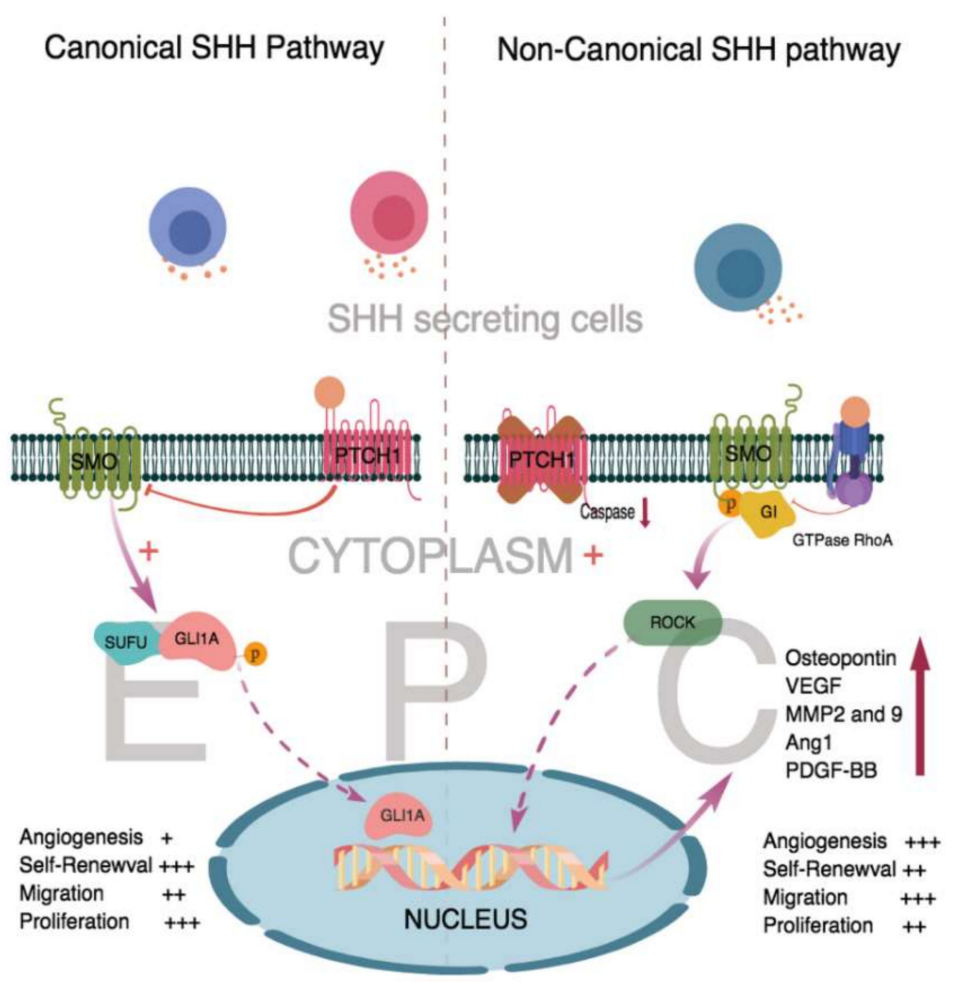

Figure 1. Canonical and Non-Canonical Sonic hedgehog (SHH) signaling pathway in endothelial progenitor cells (EPCs) and endothelial cells (ECs). SHH molecule binds and activate the 12-pass transmembrane cell surface receptor Patched 1 (PTCH 1) that inhibits the smoothened (SMO) receptor to activate the binding of suppressor of fused (SUFU) and glioma-associated oncogene homolog1-A (GILI 1A) to form a complex by autophosphorylation. EPCs are mostly activated by the non-canonical SHH signaling pathway in angiogenesis. 
Recent research in the field of vascular biology reveals significant contribution of the non-canonical SHH signaling rather than canonical SHH signaling in vascular development under homeostasis or pathological conditions $[13,17,25]$. In endothelial cells, SHH morphogens trigger the non-canonical SHH signaling pathway leading to vascular differentiation, maturation and function $[14,17-19,26,27]$. Stimulation of a confluent endothelial monolayer of cells with recombinant SHH molecules but not IHH or DHH morphogens, resulted in a change in the overall morphology of cells from the typical EC "cobblestone" shape to a swirling pattern of elongated cells oriented in bundles, a pattern characteristic of activated ECs engaged in angiogenesis [25,28].

In one of the non-canonical SHH signaling pathways, $\mathrm{SHH}$ proteins could activate membrane RhoA GTPase in a SMO/GI protein-dependent manner [25]. The membrane RhoA family of small GTPases play an important role in cell migration and invasion by orchestrating guanine nucleotide exchange factors and GTPase-activating protein complexes [29]. Cell migration mediated by RhoA GTPase signaling is specific in different cell lines. More than 20 members of the Rho family have been discovered and are divided into classical and non-typical types. The RhoA GTPase responsible for the activation of the Gi/SMO complex in ECs is less studied [30]. In vitro, the tube formation assay showed that Hh proteins stimulated tubulogenesis by inducing rapid activation of RhoA levels in human umbilical-vein ECs via SMO and GI proteins, while inhibition of RhoA activation hindered tube formation [25,31]. Binding of SHH molecule to RhoA GTPase brought forth a 3-fold increase in the concentration of RhoA GTPase, thereby delivering a strong angiogenic signal required to activate the non-canonical SMO-dependent SHH signaling pathway for the maturation of EPCs to ECs (Figure 1) [25,27,31].

Survival of ECs is mediated by a decrease in caspase-3 activity that inhibits the PTCH1 pro-apoptotic function in a SMO-independent manner [25,27]. A combined transcriptomic and proteomic approach identified a 101-gene endothelial signature that could be used to characterize endothelial commitment. The HH-interacting protein regulates GLI-dependent canonical HH signaling and is a strong negative regulator of the late endothelial progenitor cells (LEPCs). Knockdown of hedgehog-interacting protein in LEPCs improves the angiogenic activity and enhances their survival under oxidative stress [32]. Thus, exogenous administration of $\mathrm{SHH}$ could be beneficial for the survival of EPCs after the onset of ischemic events.

SHH morphogens activate the Rho-associated protein kinase (Rho/ROCK) pathway and enhances the expression of downstream matrix metalloproteinase 9 (MMP-9), osteopontin (OPN) and platelet derived growth factor (PDGF-BB) (Figure 1), which are essential for SHH-induced angiogenesis in vitro $[14,25,27]$. An in vivo mouse corneal angiogenesis model was used to investigate the potential involvement of SMO, the Rho/ROCK pathway, MMP-9, OPN and the GLI transcription factors in SHH-induced angiogenesis. Pellets containing phosphate-buffered saline (PBS) or cyclopamine (SMO protein inhibitor) alone and in combination with $\mathrm{SHH}$, were implanted and the extent of angiogenesis was evaluated by in vivo fluorescein-BS-1 lectin perfusion. PBS+ SHH significantly increased angiogenesis, which was inhibited by cyclopamine. To analyze the role of the Rho/ROCK pathway in SHH signaling, pellets containing PBS, SHH, Y27632 (ROCK inhibitor), or SHH+Y27632 (ROCK inhibitor) were implanted. Significantly enhanced downstream targets of ROCK, MMP-9 and OPN dependent angiogenesis were observed in the SHH treated group compared to those in the $\mathrm{SHH}+\mathrm{Y} 27632$ treated group that showed no significant changes [27]. A mouse corneal angiogenesis model demonstrated SHH-dependent PDGF-BB-induced pericyte cell recruitment, essential for the maturation of newly formed blood vessels [14].

Taken together, the above results prove the vital role of SHH morphogens in activating the non-canonical rather than the canonical signaling pathway in EPCs and ECs, thereby regulating migration, angiogeneic bioactivity, survival and maturation.

Gupta et al., recently reported a non-canonical SHH signaling pathway with an indirect effect of SHH molecules in mediating angiogenesis in EPCs and ECs. They demonstrated that in vitro, the effect of $\mathrm{SHH}$ on the proliferation and migration of ECs was limited by direct incubation of $\mathrm{SHH}$ 
in culture but was significantly enhanced in the presence of conditioned media from SHH-treated fibroblasts or stromal cells. In addition, treatment of fibroblasts with SHH significantly enhanced the expression profile of angiogenic growth factors including PDGF-B, VEGF-A, hepatocyte growth factor (HGF) and insulin-like growth factor (IGF). Among these, PDGF-B was most predominantly upregulated and might have contributed to the formation of large neo-vessels associated with SHH-induced indirect angiogenesis [26]. In vivo, in a corneal angiogenesis model, administration of exogenous SHH showed no significant difference in corneal angiogenesis between endothelial-specific smoothened knockout (eSmoNull) and eSmoWT mice. An in vivo hind-limb ischemia (HLI) model in eSmoNull and eSmoWT mice was used to assess the importance of SMO-dependent SHH signaling in SHH-mediated angiogenesis in ECs. The study demonstrated equal recovery in both eSmoNull and eSmoWT mice in terms of perfusion ratio, limb motor function, limb necrosis and blood vessel formation [16,26]. The results suggest the role of fibroblast-derived pro-angiogenic genes in indirectly activating angiogenesis that is independent of SMO proteins in EPCs and ECs.

\subsection{SHH Signal Transmission by Extracellular Vesicles}

Extracellular vesicles (EVs) are lipid bilayered structures, 30-150 nm in size, enclosing cargo containing messenger ribonucleic acid (mRNA), microRNAs (miRNAs), growth factors and proteins for transfer into recipient cells [33,34]. From biogenesis to release, all the EVs share three main stages, namely, (i) outward budding and fission that occur at the plasma membrane, (ii) formation of early endosome, packaging and sorting in endoplasmic reticulum to form exosomes or EVs and (iii) release of exosomes or EVs into the extracellular space [33,35]. In mammals, $\mathrm{SHH}$ is secreted on two distinct types of EVs/exosomes exhibiting distinct protein and RNA composition to directly or indirectly activate downstream target genes [36]. Vyas et al. [36] isolated two distinct exosome fractions, P150 and P450, from full-length SHH transfected HEK293T cells using differential ultracentrifugation technique. The EV pools were derived from an endocytic origin as the expression of the endocytosis protein RAB was found to be higher in both the fractions.

Regulation of the SHH signaling pathway by EV-derived miRNA is divided into three levels of activation, namely, binding of miRNA with membrane surface receptors or proteins (PTCH1 or activates Rho GTPase), subsequent binding with cytoplasmic proteins GLI1, GLI 2 and GLI 3 and the nuclear level of activation, which is the strongest among the three levels [37-39] (Figure 2). Chondrocytes isolated from osteoarthritis patients showed enhanced expression of SHH, PTCH1, GLI 1 and metalloproteinase-13, which positively correlated with the overexpression of miRNA-602 and miRNA-608 responsible for the activation of the above mentioned three levels [40]. EVs derived from cancerous cells exhibited significantly enhanced expression of SHH and GLI and positively correlated with the microvascular density (MVD) of tumor tissue, suggesting the important role played by $\mathrm{SHH}$ morphogens in cancer cell growth and metastasis by promoting the formation of microvascular network [41].

According to in vitro studies, $\mathrm{SHH}$ secreted on EVs activated downstream signal transduction in EPCs by the canonical PTCH1-GLI1 signaling or through the non-canonical signaling mediated by pro-angiogenic miRNAs, integrin-linked kinases and ROCK dependent pathway [27,31,42,43] (Figure 2). In an in vivo study, SHH-coding vector transfected CD34+ cells or EPC exosomes had strong vasculogenic potential and aided the recovery of myocardial infarcted tissues by enhancing angiogenesis and reducing left ventricular fibrosis [17]. Analysis of transcriptional profile revealed overexpression of miRNA-126a and miRNA-296 in EPC-derived exosomes and an in vivo study showed improved self-renewal and vasculogenic functions in EPCs that enhanced angiogenesis in a murine HLI model (Table 1) [44]. Taken together, the above results indicate the importance of EVs derived SHH molecules or miRNAs in postnatal angiogenesis and tumor metastasis. Current research focuses on elucidating the functions of SHH-EVs derived miRNAs to develop novel therapeutic drugs for the benefit of patients suffering from cardiovascular ischemic diseases (Table 1). 


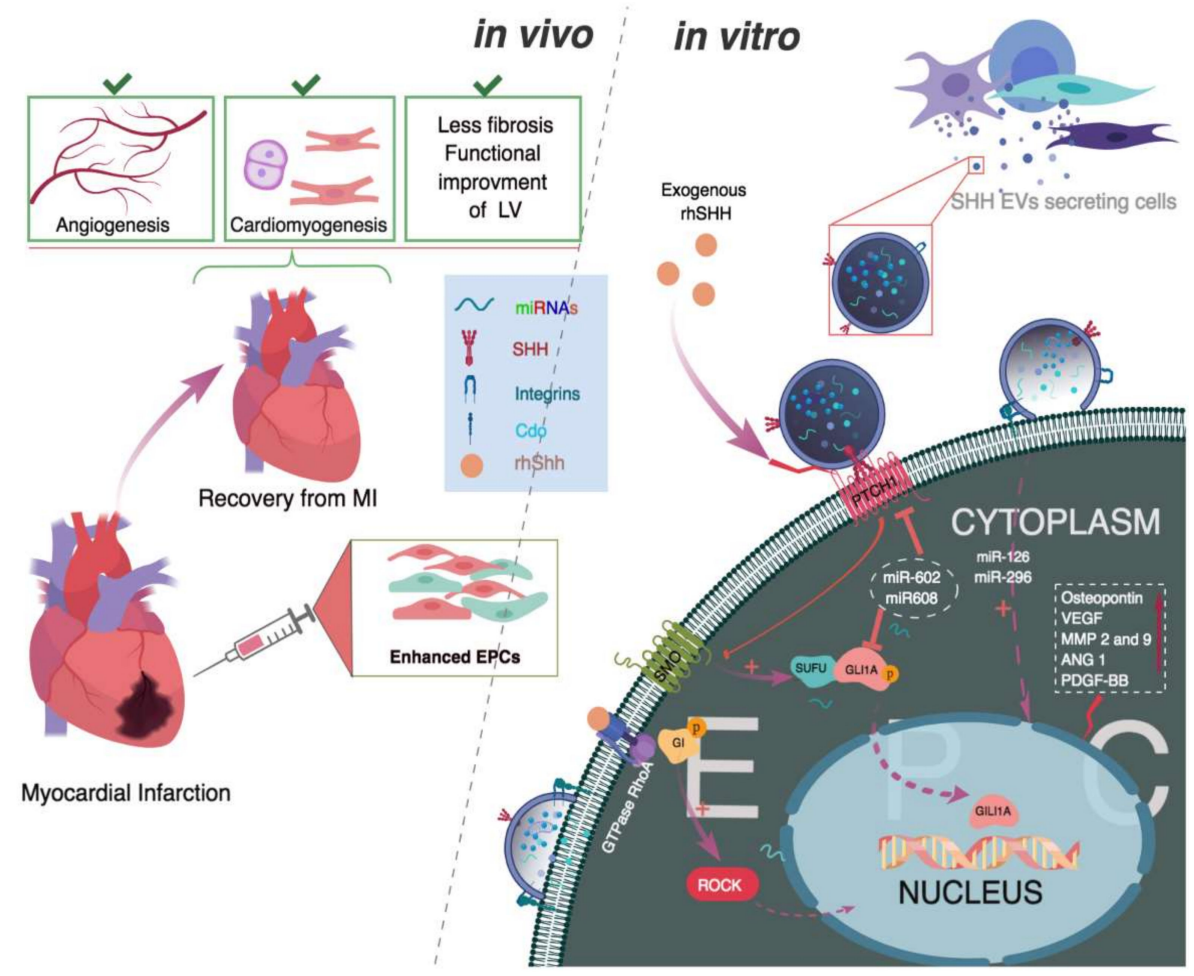

Figure 2. Sonic Hedgehog (SHH) molecule or SHH secreted on extracellular vesicles (EVs) mediated functional improvement of endothelial progenitor cells (EPCs). In vivo, administration of exogenous SHH molecules increased vasculogenic EPCs. Transplantation of enhanced EPCs was beneficial for recovery in myocardial infarction (MI).

Table 1. Summary of pro-angiogenic and anti-senescence micro-RNAs (miRNAs) in endothelial progenitor cells (EPCs) and endothelial cells (ECs).

\begin{tabular}{|c|c|c|c|c|c|}
\hline $\begin{array}{l}\text { Name of the } \\
\text { miRNA }\end{array}$ & Expression & Target Cells & Outcome & Target Genes & Ref. \\
\hline miR-126-3p & Up & $\mathrm{EPC}$ and EC & $\begin{array}{l}\text { In vitro, presence of miR126-3p increases the } \\
\text { length of tube formation. In vivo, it increases the } \\
\text { MVD in animal models with HLI. }\end{array}$ & $\begin{array}{l}\text { VEGF, ANG-1, } \\
\text { ANG-2 and } \\
\text { MMP-9 }\end{array}$ & [44] \\
\hline miR-106b-25 & Up & $\begin{array}{c}\text { EC, EPC, SCA-1 } \\
\text { and BMMSC }\end{array}$ & $\begin{array}{l}\text { Increased tube formation capacity. } \\
\text { Overexpression of individual members of the } \\
\text { miR-106b-25 cluster increases viability, } \\
\text { proliferation and migration of ECs. }\end{array}$ & $\begin{array}{l}\text { VEGF, SCA-1 } \\
\text { and FLK-1 }\end{array}$ & [45] \\
\hline miR-126 & Down & $\begin{array}{l}\text { EPC, SCA-1 } \\
\text { and Lin- }\end{array}$ & $\begin{array}{l}\text { Silencing miR-126 in animal models with HLI } \\
\text { increases mobilization of EPC, SCA- } 1 \text { and Lin- } \\
\text { cells from bone marrow to the site of injury and } \\
\text { enhanced angiogenesis. }\end{array}$ & SDF-1 & [46] \\
\hline $\mathrm{miR}-34 \mathrm{a}$ & Down & EPC & $\begin{array}{l}\text { Overexpression of miR-34a significantly } \\
\text { enhanced senescence and impairment in EPC } \\
\text { that paralleled with } 40 \% \text { reduction in SIRT1. KO } \\
\text { of SIRT1 by siRNA decreased angiogenesis and } \\
\text { increased senescence in EPCs. }\end{array}$ & $\begin{array}{l}\text { SIRT1 and } \\
\text { FOXO1 }\end{array}$ & [49] \\
\hline
\end{tabular}

Abbreviations: EPC—endothelial progenitor cell; EC—endothelial cell; HLI—hind-limb ischemia; BMMSC—bone marrow mesenchymal stromal cells; MVD—microvascular density; Lin—lineage negative cells; $\mathrm{KO}$ — knock-out; VEGF-vascular endothelial growth factor; Ang—angiopoietin; MMP—matrix metalloproteinase; SCA—stem cells antigen; FLK—-fetal liver kinase; SDF—stromal cell-derived factor; HMGA-high mobility group AT-hook; SIRT—sirtuin (silent mating type information regulation 2 homolog); FOX—Forkhead box. 


\subsection{Impaired SHH Signaling in Cardiovascular Diseases}

Cardiovascular diseases (CVD) contribute to almost 32\% of all deaths worldwide. Among them, ischemic diseases are a leading cause of morbidity and mortality [50,51]. EPCs in the peripheral bloodstream of patients with morbidities such as atherosclerosis, diabetes mellitus (DM), hypertension and obesity, together with risk-associated factors (smoking and western diet) are impaired in number, quality and function $[21,52,53]$. Preclinical studies related to DM, acute myocardial infarction (AMI), wound healing and chronic vascular inflammatory diseases indicated increased activation of endogenous SHH signaling pathway in non-treated group compared to that of the treated group, wherein exogenous administration of SHH promoted functional recovery of EPCs, resulting in enhanced angiogenesis, cardiomyogenesis and wound healing [26,54,55]. Additional studies have demonstrated the contribution of SHH molecules in the process of neovascularization in ischemic tissues in animal models of HLI and AMI, where the biological effects were brought about by an EPC enriched cell population, CD34+ cells $[17,19,56]$ (Table 2). In a study, human CD34+ cells isolated from healthy volunteers or patients suffering from Burger's disease were treated with SHH after administration of granulocyte colony-stimulating factor (G-CSF). The results indicated enhanced expression of pro-angiogenic genes in a dose-dependent manner by $\mathrm{SHH}$ protein, particularly in patient-derived CD34+ cells compared to that of CD34+ cells derived from healthy controls, in the presence or absence of G-CSF [17]. In vivo, streptozotocin-induced DM type 1 mice exhibited impaired tube-forming ability, migration and mobilization of EPCs compared to that of the healthy control group. EPCs of DM type 1 mice showed cross-talk between SHH and phosphatidylinositol-4,5-bisphosphate 3-kinase (PI3K) / AKT pathways, which decreased the activity of AKT and increased GSK-3 $\beta$ activity, resulting in the degradation of the SHH pathway transcription factor GLI1/GLI2 [57]. In human pancreatic cancer stem cells, the PI3K/AKT and SHH signaling pathways cooperate to inhibit the transcription factor GLI1/GLI2 to decrease cell viability and to induce apoptosis [58]. Compared to the control littermates, type 1 diabetic mice with myocardial infarction showed impaired SHH pathway with significantly decreased SHH, PTCH 1 and GLI1 protein levels in the myocardial tissue, resulting in extended left ventricle infarct size and reduced capillary density leading to cardiac dysfunction [59]. GLI1 protein is essential for regulating cell-cycle, survival, apoptosis, angiogenesis and migration of cells [24]. Patients with cardiovascular diseases, levels of endogenous SHH-PTCH1-GLI1 protein complex is decreased in EPCs because of chronic inflammation and risk factors. In such patients, administration of exogenous SHH molecules might aid in the recovery of PTCH1-GLI1 complex to beneficially improve the EPC functional profile $[57,59,60]$. Studies related to the transplantation of EPCs in ischemic diseases such as AMI, ischemic cardiomyopathy, heart failure, peripheral arterial disease (PAD) and stroke have documented lack of recovery of EPCs from ischemia in aged and DM patients compared to that of the control group. These results indicate a decrease in the concentration of PTCH1-GLI1 molecule or sensitivity of SHH signaling pathway receptors to EPCs to be dependent on the severity, age, type and timing of the disease [61-63]. Accordingly, studies related to aged mice showed decreased expression of SMO in the skeletal muscles [64].

Table 2. Endogenous and Exogenous Activation of Sonic Hedgehog (SHH) Signaling in Cardiovascular Diseases.

\begin{tabular}{clll}
\hline Disease Model & SHH Pathway and Cell Tx. & \multicolumn{1}{c}{ Results } & Ref. \\
\hline \multirow{2}{*}{ AMI } & $\begin{array}{l}\text { Activation of endogenous } \\
\text { and exogenous SHH } \\
\text { signaling by SHH-modified } \\
\text { human CD34+ cells and its } \\
\text { exosomes }\end{array}$ & $\begin{array}{l}\text { Treatment with SHH-modified human CD34+ cells } \\
\text { reduced infarct size, increased border zone capillary } \\
\text { density and improved cardiac function; EF, FS, } \\
\text { compared with unmodified CD34 cells or cells } \\
\text { transfected with the empty vector. }\end{array}$ & {$[$ 15] } \\
\hline AMI and Chronic MI & $\begin{array}{l}\text { Exogenous recombinant } \\
\text { SHH administration and } \\
\text { gene transfer of naked DNA } \\
\text { encoding human SHH }\end{array}$ & $\begin{array}{l}\text { MI fibrosis size and apoptotic cardiomyocytes were } \\
\text { reduced. MVD was increased. SHH gene transfer } \\
\text { enhanced the contribution of bone marrow-derived } \\
\text { endothelial progenitor cells to myocardial } \\
\text { neovascularization. }\end{array}$ & {$[56]$} \\
\hline
\end{tabular}


Table 2. Cont.

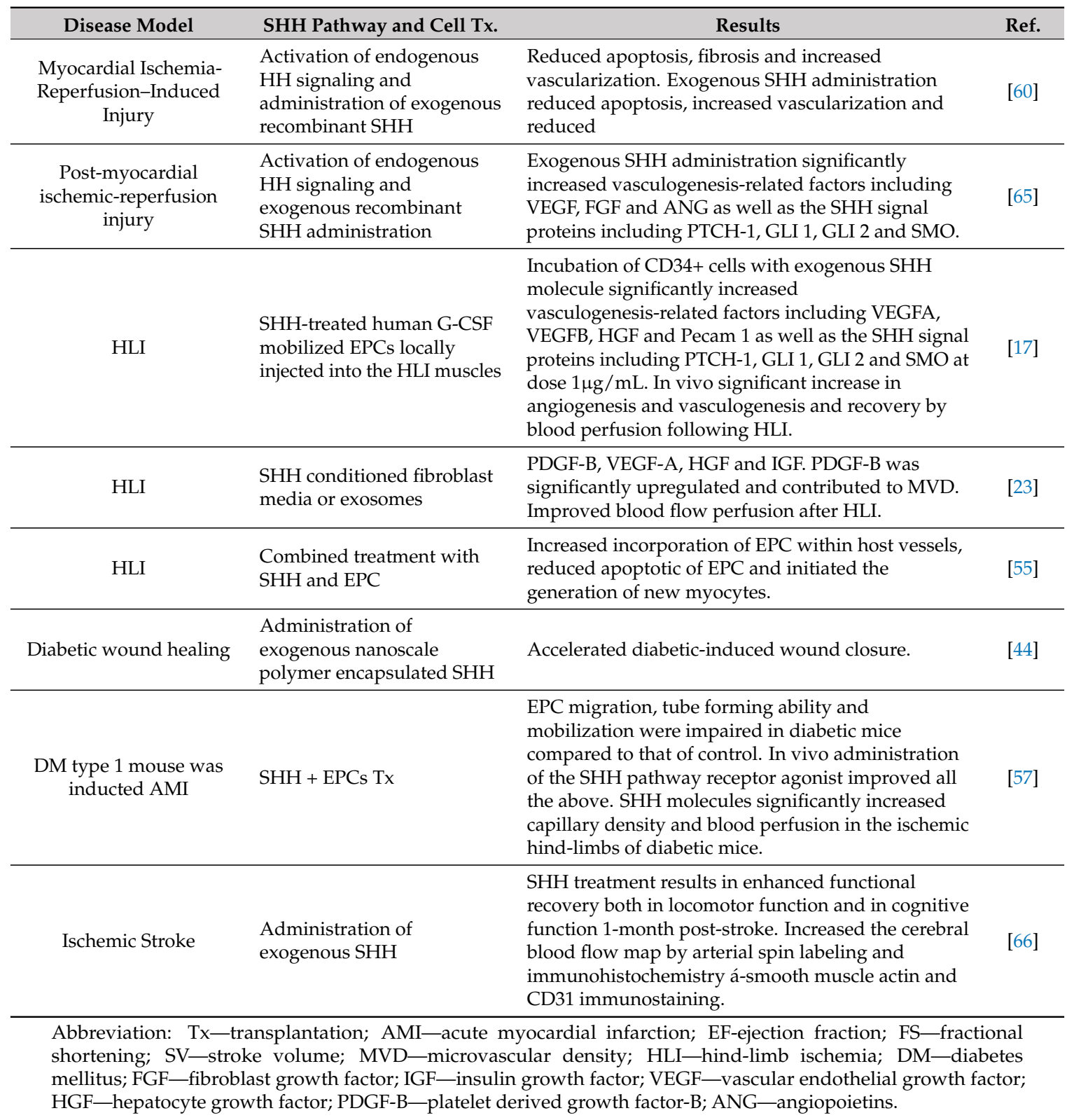

\subsection{Therapeutic Application of SHH Signaling in Cardiovascular Diseases}

In patients with end-stage ischemic disease, the effectiveness of interventional reperfusion therapy is hampered [67-69]. In such patients, EPC therapy is a promising therapeutic option for improving angiogenesis, vasculogenesis and contemporary organ preservation. Transplantation G-CSF mobilized EPCs are safe and feasible for patients with advanced coronary artery disease or PAD, who are not amenable to surgical or percutaneous revascularization [70-72]. However, efficacy of EPC mobilization with G-CSF is very low in DM and previously EPC mobilized patients because of the impaired quality and quantity of EPCs [73]. In cardiovascular patients who previously underwent cell mobilization, SHH-mediated activation of EPC is a promising option for the functional recovery of EPCs [17]. Results of preclinical studies related to the therapeutic implementation of SHH proteins or activation of the $\mathrm{SHH}$ signaling pathway beneficially improved in several ischemic disease models such as AMI [15,43], myocardial ischemic-reperfusion, HLI [17,23,45,74], stroke [75], diabetic wound healing [44], skeletal myogenesis [76], osteogenesis and bone tissue formation [77] Table 2. 
The advantages and disadvantages of the therapeutic application of SHH molecules in cardiovascular related diseases are reviewed below.

\subsection{Ischemic Heart Diseases}

A young human heart is composed of cardiomyocytes (approximately 18\%), ECs (24\%) and mesenchymal cells or fibroblasts 58\% [78]. Recent research with sophisticated cardiac single cell preparation and immunohistochemistry analysis revealed that the endothelial cells constitute over $\sim 51-54 \%$, hematopoietic-derived cells $\sim 3 \%$ and fibroblasts under equating to $\sim 11 \%$ of the total cells of the heart when assuming $\sim 30-33 \%$ of the cells to be cardiomyocytes [79]. As endothelial cells are the major cellular component of the cardiac tissue, together with $\mathrm{SHH}$ molecules, they could be therapeutically exploited to benefit patients suffering from cardiovascular diseases (Figure 2). In the therapeutic application of EPCs $+\mathrm{SHH}$ molecules, $\mathrm{SHH}$ signaling preserve cardiac function and improve cardiac recovery in the context of myocardial ischemia. To this end, combination therapy using intramyocardial SHH gene transfer and AMD3100-induced progenitor-cell mobilization significantly improved the recovery of cardiac function after the onset of MI in mouse. Mice administered with the combination therapy demonstrated increased MVD, reduced left ventricle fibrosis area and significantly enhanced expression of SDF-1 $\alpha$ after MI [80]. One of the limitations associated with the broad use of SHH molecules in therapy is its short half-life in the body. In this regard, controlled delivery of SHH morphogens to the ischemic myocardium using a coacervate delivery system prolongs the therapeutic efficacy of SHH molecules. The coacervate delivery system protects the $\mathrm{SHH}$ molecules from degradation and promotes controlled release of the molecule for a period of over 3 weeks [81]. Transplantation of EPCs together with controlled delivery of SHH morphogens to the ischemic myocardium would be a promising therapeutic tool to treat cardiovascular diseases. Various therapeutic applications of endogenous and exogenous activation of SHH signaling in AMI and myocardial ischemia-reperfusion-induced injury models are summarized in Table 2.

\subsection{Peripheral Arterial Diseases}

Majority of the therapeutic effects of SHH signaling were investigated using PAD model in mouse and rat. The importance of the therapeutic application of SHH is based on its regulatory function associated with the development of limbs during embryogenesis and postnatal skeletal myogenesis, angiogenesis, vasculogenesis and neurogenesis $[6,7,40]$. Endogenous $\mathrm{SHH}$ promotes infiltration of macrophages. Myocytes of mice deficient for SHH signaling showed enhanced expression of VEGF-A with a transient increase in angiogenesis compared to that of the healthy controls. These results indicate the ability of SHH molecules to limit inflammation and angiogenesis indirectly by signaling in myocytes, whereas exogenous administration of $\mathrm{SHH}$ molecules promoted ischemia-induced angiogenesis and skeletal myogenesis (Table 2) [19,74,76]. In a HLI model in aged mice, combination of SHH gene transfer and transplantation of bone marrow-derived EPCs (BM-EPCs) could effectively promote angiogenesis and muscle regeneration compared to monotherapy with BM-EPCs. Treatment with SHH+ EPCs enhanced the incorporation of EPCs into the host blood vessels, suggesting a promising role of $\mathrm{SHH}$ in increasing the migration of transplanted EPCs into the site of ischemia to enhance angiogenesis and vasculogenesis. In vivo, combined treatment with SHH+ EPCs significantly reduced apoptosis in EPCs and increased proliferation of myoblast proliferation after the onset of HLI Table 2 [55]. These results suggest that combined treatment with SHH and EPC could accelerate proliferation of quiescent myogenic stem cells (satellite cells) and promote myotube formation by accelerating their fusion, eventually leading to the formation of mature myofibers supplied with new blood vessels.

\subsection{Post DM Complications}

Patients with DM are at increased risk of cardiovascular diseases and associated clinical complications. DM is estimated to affect 552 million people worldwide by 2030 [82]. A recent 
cohort study involving 1.9 million people with type 2 diabetes and incidence of cardiovascular diseases showed a strong positive association between type 2 diabetes and PADs, ischemic stroke, stable angina, heart failure and non-fatal MI [83]. Thus, post diabetic clinical complications are a global burden that requires new therapeutic strategies. Animal models with DM type 1 along with AMI or HLI were used for preclinical investigation of Hh signaling. Results from these experiments showed downstream HH signaling proteins such as PTCH1, SMO, GLI 1, GLI 2 and GLI 3 to be functionally impaired, indicating impairment of $\mathrm{SHH}$ signaling pathway in cardiovascular diseases. Combined treatment with exogenous recombinant $\mathrm{SHH}$ molecule and EPCs significantly improved the histological and functional parameters in experimental animals that indicated enhanced expression of PTCH1, SMO and GLI 1, GLI 2 and GLI 3 as detected by the transcriptome analysis [57,59]. In a diabetic animal model, administration of nanoscale polymer SHH conjugates accelerated wound closure via activation of $\mathrm{SHH}$ pathway. The beneficial effects of $\mathrm{SHH}$ treatment were evident based on wound revascularization detected using immunohistochemistry that quantified endothelial cells, CD31 and formation of neovascular structures in the wound tissues [54].

Following post-stroke, immediate treatment with $\mathrm{SHH}$ pathway agonists significantly increased the expression of vasculogenesis-related factors including VEGF, FGF and ANG, together with SHH signaling proteins PTCH1, GLI 1, GLI 2 and SMO. SHH treatment improved the neurological scores, reduced the infarct volume, promoted angiogenesis and neuronal survival in the ischemic boundary zone [75]. Strikingly, delayed treatment (post 3-8 days) with SHH pathway agonists enhanced the recovery of locomotor behavioral and cognitive function within 1 month of the onset of stroke, suggesting that a prolonged treatment window for potential treatment strategy can be modulated for SHH pathway post-stroke Table 2 [66].

\section{Conclusions}

SHH signaling pathway is a key regulator of postnatal vasculogenesis. In cardiovascular patients, endogenous $\mathrm{SHH}$ signaling pathway is impaired to varying degrees depending on the severity of the disease such as AMI, stroke and PAD due to the mitigated angiogenic potential of EPCs. Most of the preclinical experimental studies related to CVDs have shown that treatment with SHH molecules and EPCs could significantly enhance angiogenesis, vasculogenesis, cardiomyogenesis, skeletal myogenesis and neurogenesis. These therapeutic effects were evident even with delayed treatment. Cross-talk between SHH- and other signaling pathways, or key regulators such as wingless/integrated (WNT) or Notch may also be involved in maintaining the functional activity of EPC in angiogenesis. Thus, further research is needed to elucidate the cross-talk of SHH signaling with WNT, Notch, or protein kinase A (PKA). To date, most of the data available related to $\mathrm{SHH}$ signaling are derived from in vitro experiments and are difficult to be verified in vivo because of the presence of numerous signaling pathways and the associated cross-talk between them in an experimental organism. Thus, further research is required to explore the possibility of exploiting $\mathrm{SHH}$ signaling as a therapeutic tool for treating CVDs.

Author Contributions: Conception and design, acquisition of data and writing of the manuscript: A.A.S., A.K.S. Final approval: R.P \& T.A.

Funding: This work was supported by the International Scholarship of the First President of Kazakhstan for studying abroad "BOLASHAQ": A.A.S and AMED Japan Regenerative Medicine Project (15BK0104012H003) to T.A.

Conflicts of Interest: The authors declare no conflict of interests.

\section{References}

1. Asahara, T.; Murohara, T.; Sullivan, A.; Silver, M.; Zee, R.v.d.; Li, T.; Witzenbichler, B.; Schatteman, G.; Isner, J.M. Isolation of putative progenitor endothelial cells for angiogenesis. Science 1997, 275, $964-966$. [CrossRef] [PubMed] 
2. Asahara, T.; Kawamoto, A.; Masuda, H. Concise review: Circulating endothelial progenitor cells for vascular medicine. Stem Cell 2011, 29, 1650-1655. [CrossRef] [PubMed]

3. Asahara, T.; Masuda, H.; Takahashi, T.; Kalka, C.; Pastore, C.; Silver, M.; Kearne, M.; Magner, M.; Isner, J.M. Bone marrow origin of endothelial progenitor cells responsible for postnatal vasculogenesis in physiological and pathological neovascularization. Circ. Res. 1999, 85, 221-228. [CrossRef] [PubMed]

4. Ingram, D.A.; Mead, L.E.; Tanaka, H.; Meade, V.; Fenoglio, A.; Mortell, K.; Pollok, K.; Ferkowicz, M.J.; Gilley, D.; Yoder, M.C. Identification of a novel hierarchy of endothelial progenitor cells using human peripheral and umbilical cord blood. Blood 2004, 104, 21-28. [CrossRef] [PubMed]

5. Aicher, A.; Rentsch, M.; Sasaki, K.; Ellwart, J.W.; Fandrich, F.; Siebert, R.; Cooke, J.P.; Dimmeler, S.; Heeschen, C. Nonbone marrow-derived circulating progenitor cells contribute to postnatal neovascularization following tissue ischemia. Circ. Res. 2007, 100, 581-589. [CrossRef] [PubMed]

6. Chinnaiya, K.; Tickle, C.; Towers, M. Sonic hedgehog-expressing cells in the developing limb measure time by an intrinsic cell cycle clock. Nat. Commun. 2014, 5, 4230. [CrossRef] [PubMed]

7. Tickle, C.; Towers, M. Sonic hedgehog signaling in limb development. Front. Cell Dev. Biol. 2017, 5, 14. [CrossRef] [PubMed]

8. Yao, P.J.; Petralia, R.S.; Mattson, M.P. Sonic hedgehog signaling and hippocampal neuroplasticity. Trends Neurosci. 2016, 39, 840-850. [CrossRef] [PubMed]

9. Yao, P.J.; Petralia, R.S.; Ott, C.; Wang, Y.X.; Lippincott-Schwartz, J.; Mattson, M.P. Dendrosomatic sonic hedgehog signaling in hippocampal neurons regulates axon elongation. J. Neurosci. 2015, 35, 16126-16141. [CrossRef] [PubMed]

10. Ihrie, R.A.; Shah, J.K.; Harwell, C.C.; Levine, J.H.; Guinto, C.D.; Lezameta, M.; Kriegstein, A.R.; Alvarez-Buylla, A. Persistent sonic hedgehog signaling in adult brain determines neural stem cell positional identity. Neuron 2011, 71, 250-262. [CrossRef] [PubMed]

11. Lee, S.W.; Moskowitz, M.A.; Sims, J.R. Sonic hedgehog inversely regulates the expression of angiopoietin-1 and angiopoietin-2 in fibroblasts. Int. J. Mol. Med. 2007, 19, 445-451. [CrossRef] [PubMed]

12. Jeong, M.-H.; Leem, Y.-E.; Kim, H.-J.; Kang, K.; Cho, H.; Kang, J.-S. A shh coreceptor cdo is required for efficient cardiomyogenesis of pluripotent stem cells. J. Mol. Cell. Cardiol. 2016, 93, 57-66. [CrossRef] [PubMed]

13. Fuchs, S.; Dohle, E.; Kirkpatrick, C.J. Sonic hedgehog-mediated synergistic effects guiding angiogenesis and osteogenesis. Vitam. Horm. 2012, 88, 491-506. [PubMed]

14. Yao, Q.; Renault, M.-A.; Chapouly, C.; Vandierdonck, S.; Belloc, I.; Jaspard-Vinassa, B.; DanielLamazière, J.-M.; Laffargue, M.; Merched, A.; Desgranges, C.; et al. Sonic hedgehog mediates a novel pathway of pdgf-bb-dependent vessel maturation. Blood 2014, 123. blood-2013. [CrossRef] [PubMed]

15. Fu, J.R.; Liu, W.L.; Zhou, J.F.; Sun, H.Y.; Xu, H.Z.; Luo, L.; Zhang, H.; Zhou, Y.F. Sonic hedgehog protein promotes bone marrow-derived endothelial progenitor cell proliferation, migration and vegf production via pi 3-kinase/akt signaling pathways. Acta Pharmacol. Sin. 2006, 27, 685-693. [CrossRef] [PubMed]

16. Pola, R.; Ling, L.E.; Silver, M.; Corbley, M.J.; Kearney, M.; Blake Pepinsky, R.; Shapiro, R.; Taylor, F.R.; Baker, D.P.; Asahara, T.; et al. The morphogen sonic hedgehog is an indirect angiogenic agent upregulating two families of angiogenic growth factors. Nat. Med. 2001, 7, 706-711. [CrossRef] [PubMed]

17. Mackie, A.R.; Klyachko, E.; Thorne, T.; Schultz, K.M.; Millay, M.; Ito, A.; Kamide, C.E.; Liu, T.; Gupta, R.; Sahoo, S.; et al. Sonic hedgehog-modified human cd34+ cells preserve cardiac function after acute myocardial infarction. Circ. Res. 2012, 122, 312-321. [CrossRef] [PubMed]

18. Straface, G.; Aprahamian, T.; Flex, A.; Gaetani, E.; Biscetti, F.; Smith, R.C.; Pecorini, G.; Pola, E.; Angelini, F.; Stigliano, E.; et al. Sonic hedgehog regulates angiogenesis and myogenesis during post-natal skeletal muscle regeneration. J. Cell. Mol. Med. 2009, 13, 2424-2435. [CrossRef] [PubMed]

19. Kanaya, K.; Li, M.; Okazaki, T.; Nakamura, T.; Horii-Komatsu, M.; Alev, C.; Akimaru, H.; Kawamoto, A.; Akashi, H.; Tanaka, H.; et al. Sonic hedgehog signaling regulates vascular differentiation and function in human cd34 positive cells: Vasculogenic cd34+ cells with sonic hedgehog. Stem Cell Res. 2015, 14, 165-176. [CrossRef] [PubMed]

20. Pola, R.; Ling, L.E.; Aprahamian, T.R.; Barban, E.; Bosch-Marce, M.; Curry, C.; Corbley, M.; Kearney, M.; Isner, J.M.; Losordo, D.W. Postnatal recapitulation of embryonic hedgehog pathway in response to skeletal muscle ischemia. Circulation 2003, 108, 479-485. [CrossRef] [PubMed] 
21. Briscoe, J.; Thérond, P.P. The mechanisms of hedgehog signalling and its roles in development and disease. Nat. Rev. Mol. Cell Biol. 2013, 14, 416. [CrossRef] [PubMed]

22. Zhang, Z.; Shen, L.; Law, K.; Zhang, Z.; Liu, X.; Hua, H.; Li, S.; Huang, H.; Yue, S.; Hui, C.-C.; et al. Suppressor of fused chaperones gli proteins to generate transcriptional responses to sonic hedgehog signaling. Mol. Cell. Biol. 2017, 37, e00421-16. [CrossRef] [PubMed]

23. Rimkus, T.K.; Carpenter, R.L.; Qasem, S.; Chan, M.; Lo, H.W. Targeting the sonic hedgehog signaling pathway: Review of smoothened and gli inhibitors. Cancers 2016, 8, 22. [CrossRef] [PubMed]

24. Mastrangelo, E.; Milani, M. Role and inhibition of gli1 protein in cancer. Lung Cancer 2018, 9, 35-43. [CrossRef] [PubMed]

25. Chinchilla, P.; Xiao, L.; Kazanietz, M.G.; Riobo, N.A. Hedgehog proteins activate pro-angiogenic responses in endothelial cells through non-canonical signaling pathways. Cell Cycle 2010, 9, 570-579. [CrossRef] [PubMed]

26. Gupta, R.; Mackie, A.R.; Misener, S.; Liu, L.; Losordo, D.W.; Kishore, R. Endothelial smoothened-dependent hedgehog signaling is not required for sonic hedgehog induced angiogenesis or ischemic tissue repair. Lab. Investig. 2018, 98, 682-691. [CrossRef] [PubMed]

27. Renault, M.A.; Roncalli, J.; Tongers, J.; Thorne, T.; Klyachko, E.; Misener, S.; Volpert, O.V.; Mehta, S.; Burg, A.; Luedemann, C.; et al. Sonic hedgehog induces angiogenesis via rho kinase-dependent signaling in endothelial cells. J. Mol. Cell Cardiol. 2010, 49, 490-498. [CrossRef] [PubMed]

28. Abdelmonem, M.; Kassem, S.H.; Gabr, H.; Shaheen, A.A.; Aboushousha, T. Avemar and echinacea extracts enhance mobilization and homing of $\mathrm{cd} 34(+)$ stem cells in rats with acute myocardial infarction. Stem Cell Res. Ther. 2015, 6, 17. [CrossRef] [PubMed]

29. Fritz, R.D.; Pertz, O. The dynamics of spatio-temporal rho gtpase signaling: Formation of signaling patterns. F1000Res. 2016, 5, 749. [CrossRef] [PubMed]

30. Lawson, C.D.; Ridley, A.J. Rho gtpase signaling complexes in cell migration and invasion. J. Cell Biol. 2018, 217. jcb-201612069. [CrossRef] [PubMed]

31. Bryan, B.A.; Dennstedt, E.; Mitchell, D.C.; Walshe, T.E.; Noma, K.; Loureiro, R.; Saint-Geniez, M.; Campaigniac, J.P.; Liao, J.K.; D'Amore, P.A. Rhoa/rock signaling is essential for multiple aspects of vegf-mediated angiogenesis. FASEB J. 2010, 24, 3186-3195. [CrossRef] [PubMed]

32. Lee, B.N.R.; Son, Y.S.; Lee, D.; Choi, Y.J.; Kwon, S.M.; Chang, H.K.; Kim, P.H.; Cho, J.Y. Hedgehog-interacting protein (hip) regulates apoptosis evasion and angiogenic function of late endothelial progenitor cells. Sci. Rep. 2017, 7, 12449. [CrossRef] [PubMed]

33. Raposo, G.; Stoorvogel, W. Extracellular vesicles: Exosomes, microvesicles and friends. J. Cell. Boil. 2013, 200, 373-383. [CrossRef] [PubMed]

34. Théry, C.; Zitvogel, L.; Amigorena, S. Exosomes: Composition, biogenesis and function. Nat. Rev. Immunol. 2002, 2, 569. [CrossRef] [PubMed]

35. Mol, E.A.; Goumans, M.J.; Doevendans, P.A.; Sluijter, J.P.G.; Vader, P. Higher functionality of extracellular vesicles isolated using size-exclusion chromatography compared to ultracentrifugation. Nanomedicine 2017, 13, 2061-2065. [CrossRef] [PubMed]

36. Vyas, N.; Walvekar, A.; Tate, D.; Lakshmanan, V.; Bansal, D.; Cicero, A.L.; Raposo, G.; Palakodeti, D.; Dhawan, J. Vertebrate hedgehog is secreted on two types of extracellular vesicles with different signaling properties. Sci. Rep. 2014, 4, 7357. [CrossRef] [PubMed]

37. Fattahi, S.; Pilehchian Langroudi, M.; Akhavan-Niaki, H. Hedgehog signaling pathway: Epigenetic regulation and role in disease and cancer development. J. Cell Physiol. 2018, 233, 5726-5735. [CrossRef] [PubMed]

38. Ferretti, E.; Smaele, E.D.; Miele, E.; Laneve, P.; Po, A.; Pelloni, M.; Paganelli, A.; Marcotullio, L.D.; Caffarelli, E.; Screpanti, I.; et al. Concerted microrna control of hedgehog signalling in cerebellar neuronal progenitor and tumour cells. EMBO J. 2008, 172, 2616-2627. [CrossRef] [PubMed]

39. Ma, X.; Wang, J.; Li, J.; Ma, C.; Chen, S.; Lei, W.; Yang, Y.; Liu, S.; Bihl, J.; Chen, C. Loading mir-210 in endothelial progenitor cells derived exosomes boosts their beneficial effects on hypoxia/ reoxygeneation-injured human endothelial cells via protecting mitochondrial function. Cell. Physiol. Biochem. 2018, 46, 664-675. [CrossRef] [PubMed]

40. Akhtar, N.; Makki, M.S.; Haqqi, T.M. Microrna-602 and microrna-608 regulate sonic hedgehog expression via target sites in the coding region in human chondrocytes. Arthritis Rheumatol. 2015, 67, 423-434. [CrossRef] [PubMed] 
41. Huaitong, X.; Yuanyong, F.; Yueqin, T.; Peng, Z.; Wei, S.; Kai, S. Microvesicles releasing by oral cancer cells enhance endothelial cell angiogenesis via shh/rhoa signaling pathway. Cancer Boil. Ther. 2017, 18, 783-791. [CrossRef] [PubMed]

42. Martinez, M.C.; Andriantsitohaina, R. Microparticles in angiogenesis: Therapeutic potential. Circ. Res. 2011, 109, 110-119. [CrossRef] [PubMed]

43. Barakat, B.; Yu, L.; Lo, C.; Vu, D.; De Luca, E.; Cain, J.E.; Martelotto, L.G.; Dedhar, S.; Sadler, A.J.; Wang, D.; et al. Interaction of smoothened with integrin-linked kinase in primary cilia mediates hedgehog signalling. EMBO Rep. 2013, 14, 837-844. [CrossRef] [PubMed]

44. Mathiyalagan, P.; Liang, Y.; Kim, D.; Misener, S.; Thorne, T.; Kamide, C.E.; Klyachko, E.; Losordo, D.W.; Hajjar, R.J.; Sahoo, S. Angiogenic mechanisms of human cd34(+) stem cell exosomes in the repair of ischemic hindlimb. Circ. Res. 2017, 120, 1466-1476. [CrossRef] [PubMed]

45. Semo, J.; Sharir, R.; Afek, A.; Avivi, C.; Barshack, I.; Maysel-Auslender, S.; Krelin, Y.; Kain, D.; Entin-Meer, M.; Keren, G.; et al. The 106b 25 microRNA cluster is essential for neovascularization after hindlimb ischaemia in mice. Eur. Heart J. 2014, 35, 3212-3223. [CrossRef] [PubMed]

46. Van Solingen, C.; de Boer, H.C.; Bijkerk, R.; Monge, M.; van Oeveren-Rietdijk, A.M.; Seghers, L.; de Vries, M.R.; van der Veer, E.P.; Quax, P.H.; Rabelink, T.J.; et al. Microrna-126 modulates endothelial sdf-1 expression and mobilization of sca-1(+)/lin(-) progenitor cells in ischaemia. Cardiovasc. Res. 2011, 92, 449-455. [CrossRef] [PubMed]

47. Zhu, S.; Deng, S.; Ma, Q.; Zhang, T.; Jia, C.; Zhuo, D.; Yang, F.; Wei, J.; Wang, L.; Dykxhoorn, D.M.; et al. Microrna-10a* and microrna-21 modulate endothelial progenitor cell senescence via suppressing high-mobility group a2. Circ. Res. 2013, 112, 152-164. [CrossRef] [PubMed]

48. Wang, H.W.; Lo, H.H.; Chiu, Y.L.; Chang, S.J.; Huang, P.H.; Liao, K.H.; Tasi, C.F.; Wu, C.H.; Tsai, T.N.; Cheng, C.C.; et al. Dysregulated mir-361-5p/vegf axis in the plasma and endothelial progenitor cells of patients with coronary artery disease. PLoS ONE 2014, 9, e98070. [CrossRef] [PubMed]

49. Zhao, T.; Li, J.; Chen, A.F. MicroRNA-34a induces endothelial progenitor cell senescence and impedes its angiogenesis via suppressing silent information regulator 1. Am. J. Physiol. Endocrinol. Metab. 2010, 299, E110-E116. [CrossRef] [PubMed]

50. The Lancet Life, death and disability in 2016. Lancet 2017, 390, 1083. [CrossRef]

51. Paschalaki, K.E.; Starke, R.D.; Hu, Y.; Mercado, N.; Margariti, A.; Gorgoulis, V.G.; Randi, A.M.; Barnes, P.J. Dysfunction of endothelial progenitor cells from smokers and chronic obstructive pulmonary disease patients due to increased DNA damage and senescence. Stem Cells 2013, 31, 2813-2826. [CrossRef] [PubMed]

52. Schmidt-Lucke, C.; Rössig, L.; Fichtlscherer, S.; Vasa, M.; Britten, M.; Kämper, U.; Dimmeler, S.; Zeiher, A.M. Reduced number of circulating endothelial progenitor cells predicts future cardiovascular events: Proof of concept for the clinical importance of endogenous vascular repair. Circulation 2005, 111, 2981-2987. [CrossRef] [PubMed]

53. Wils, J.; Favre, J.; Bellien, J. Modulating putative endothelial progenitor cells for the treatment of endothelial dysfunction and cardiovascular complications in diabetes. Pharmacol. Ther. 2017, 170, 98-115. [CrossRef] [PubMed]

54. Han, B.W.; Layman, H.; Rode, N.A.; Conway, A.; Schaffer, D.V.; Boudreau, N.J.; Jackson, W.M.; Healy, K.E. Multivalent conjugates of sonic hedgehog accelerate diabetic wound healing. Tissue Eng. Part A 2015, 21, 2366-2378. [CrossRef] [PubMed]

55. Palladino, M.; Gatto, I.; Neri, V.; Stigliano, E.; Smith, R.C.; Pola, E.; Straino, S.; Gaetani, E.; Capogrossi, M.; Leone, G.; et al. Combined therapy with sonic hedgehog gene transfer and bone marrow-derived endothelial progenitor cells enhances angiogenesis and myogenesis in the ischemic skeletal muscle. J. Vasc. Res. 2012, 49, 425-431. [CrossRef] [PubMed]

56. Kusano, K.F.; Pola, R.; Murayama, T.; Curry, C.; Kawamoto, A.; Iwakura, A.; Shintani, S.; Ii, M.; Asai, J.; Tkebuchava, T.; et al. Sonic hedgehog myocardial gene therapy: Tissue repair through transient reconstitution of embryonic signaling. Nat. Med. 2005, 11, 1197-1204. [CrossRef] [PubMed]

57. Qin, Y.; He, Y.H.; Hou, N.; Zhang, G.S.; Cai, Y.; Zhang, G.P.; Xiao, Q.; He, L.S.; Li, S.J.; Yi, Q.; et al. Sonic hedgehog improves ischemia-induced neovascularization by enhancing endothelial progenitor cell function in type 1 diabetes. Mol. Cell. Endocrinol. 2016, 423, 30-39. [CrossRef] [PubMed] 
58. Sharma, N.; Nanta, R.; Sharma, J.; Gunewardena, S.; Singh, K.P.; Shankar, S.; Srivastava, R.K. Pi3k/akt/mtor and sonic hedgehog pathways cooperate together to inhibit human pancreatic cancer stem cell characteristics and tumor growth. Oncotarget 2015, 6, 32039-32060. [CrossRef] [PubMed]

59. Xiao, Q.; Hou, N.; Wang, Y.P.; He, L.S.; He, Y.H.; Zhang, G.P.; Yi, Q.; Liu, S.M.; Chen, M.S.; Luo, J.D. Impaired sonic hedgehog pathway contributes to cardiac dysfunction in type 1 diabetic mice with myocardial infarction. Cardiovasc. Res. 2012, 95, 507-516. [CrossRef] [PubMed]

60. Bijlsma, M.F.; Leenders, P.J.A.; Janssen, B.J.A.; Peppelenbosch, M.P.; Cate, H.T.; Spek, C.A. Endogenous hedgehog expression contributes to myocardial ischemia-reperfusion-induced injury. Exp. Biol. Med. 2008, 33, 989-996. [CrossRef] [PubMed]

61. Teraa, M.; Sprengers, R.W.; Schutgens, R.E.; Slaper-Cortenbach, I.C.; van der Graaf, Y.; Algra, A.; van der Tweel, I.; Doevendans, P.A.; Mali, W.P.; Moll, F.L.; et al. Effect of repetitive intra-arterial infusion of bone marrow mononuclear cells in patients with no-option limb ischemia: The randomized, double-blind, placebo-controlled rejuvenating endothelial progenitor cells via transcutaneous intra-arterial supplementation (juventas) trial. Circulation 2015, 131, 851-860. [PubMed]

62. Loomans, C.J.M.; Koning, E.J.P.D.; Staal, F.J.T.; Rookmaaker, M.B.; Verseyden, C.; Boer, H.C.D.; Verhaar, M.C.; Braam, B.; Rabelink, T.J.; Zonneveld, A.-J.V. Endothelial progenitor cell dysfunction. Diabetes 2004, 53, 159-199. [CrossRef]

63. Zimmet, H.; Porapakkham, P.; Sata, Y.; Haas, S.J.; Itescu, S.; Forbes, A.; Krum, H. Short- and long-term outcomes of intracoronary and endogenously mobilized bone marrow stem cells in the treatment of st-segment elevation myocardial infarction: A meta-analysis of randomized control trials. Eur. J. Heart Failur. 2014, 14, 91-105. [CrossRef] [PubMed]

64. Renault, M.-A.; Robbesyn, F.; Chapouly, C.; Yao, Q.; Vandierdonck, S.; Reynaud, A.; Belloc, I.; Traiffort, E.; Ruat, M.; Desgranges, C.; et al. Hedgehog-dependent regulation of angiogenesis and myogenesis is impaired in aged mice. Circ. Res. 2013, 33. [CrossRef] [PubMed]

65. Guo, W.; Yi, X.; Ren, F.; Liu, L.; Wu, S.; Yang, J. Activation of shh signaling pathway promotes vasculogenesis in post-myocardial ischemic-reperfusion injury. Int. J. Clin. Exp. Pathol. 2015, 8, 12464-12472. [PubMed]

66. Jin, Y.; Barnett, A.; Zhang, Y.; Yu, X.; Luo, Y. Poststroke sonic hedgehog agonist treatment improves functional recovery by enhancing neurogenesis and angiogenesis. Stroke 2017, 48, 1636-1645. [CrossRef] [PubMed]

67. Bisdas, T.; Borowski, M.; Stavroulakis, K.; Torsello, G.; Collaborators, C.; Adili, F.; Balzer, K.; Billing, A.; Böckler, D.; Brixner, D.; et al. Endovascular therapy versus bypass surgery as first-line treatment strategies for critical limb ischemia. JACC Cardiovasc. Interv. 2016, 24, 2557-2565. [CrossRef] [PubMed]

68. Fowkes, F.G.; Rudan, D.; Rudan, I.; Aboyans, V.; Denenberg, J.O.; McDermott, M.M.; Norman, P.E.; Sampson, U.K.; Williams, L.J.; Mensah, G.A.; et al. Comparison of global estimates of prevalence and risk factors for peripheral artery disease in 2000 and 2010: A systematic review and analysis. Lancet 2013, 382, 1329-1340. [CrossRef]

69. Jones, W.S.; Dolor, R.J.; Hasselblad, V.; Vemulapalli, S.; Subherwal, S.; Heidenfelder, B.; Patel, M.R. Comparative effectiveness of endovascular and surgical revascularization for patients with peripheral artery disease and critical limb ischemia: Systematic review of revascularization in critical limb ischemia. Am. Heart J. 2014, 167, 489-498. [CrossRef] [PubMed]

70. Liotta, F.; Annunziato, F.; Castellani, S.; Boddi, M.; Alterini, B.; Castellini, G.; Mazzanti, B.; Cosmi, L.; Acquafresca, M.; Bartalesi, F.; et al. Therapeutic efficacy of autologous non-mobilized enriched circulating endothelial progenitors in patients with critical limb ischemia- the scelta trial. Circ. J. 2018, 82, 1688-1698. [CrossRef] [PubMed]

71. Fujita, Y.; Kinoshita, M.; Furukawa, Y.; Nagano, T.; Hashimoto, H.; Hirami, Y.; Kurimoto, Y.; Arakawa, K.; Yamazaki, K.; Okada, Y.; et al. Phase ii clinical trial of cd34+ cell therapy to explore endpoint selection and timing in patients with critical limb ischemia. J. Gerontol. A Biol. Sci. Med. Sci. 2014, 78, 490-501. [CrossRef]

72. Losordo, D.W.; Henry, T.D.; Davidson, C.; Sup Lee, J.; Costa, M.A.; Bass, T.; Mendelsohn, F.; Fortuin, F.D.; Pepine, C.J.; Traverse, J.H.; et al. Intramyocardial, autologous cd34+ cell therapy for refractory angina. Circ. Res. 2011, 109, 428-436. [CrossRef] [PubMed]

73. Fadini, G.P.; Albiero, M.; Kreutzenberg, S.V.D.; Boscaro, E.; Cappellari, R.; Marescotti, M.; Poncina, N.; Agostini, C.; Avogaro, A. Diabetes impairs stem cell and proangiogenic cell mobilization in humans. Diabetes Care 2013, 36, DC_121084. [CrossRef] [PubMed] 
74. Caradu, C.; Guy, A.; James, C.; Reynaud, A.; Gadeau, A.P.; Renault, M.A. Endogenous sonic hedgehog limits inflammation and angiogenesis in the ischaemic skeletal muscle of mice. Cardiovasc. Res. 2018, 114, 759-770. [CrossRef] [PubMed]

75. Chen, S.C.; Huang, M.; He, Q.W.; Zhang, Y.; Opoku, E.N.; Yang, H.; Jin, H.J.; Xia, Y.P.; Hu, B. Administration of sonic hedgehog protein induces angiogenesis and has therapeutic effects after stroke in rats. Neuroscience 2017, 352, 285-295. [CrossRef] [PubMed]

76. Piccioni, A.; Gaetani, E.; Neri, V.; Gatto, I.; Palladino, M.; Silver, M.; Smith, R.C.; Giarretta, I.; Pola, E.; Hlatky, L.; et al. Sonic hedgehog therapy in a mouse model of age-associated impairment of skeletal muscle regeneration. J. Gerontol. A Biol. Sci. Med. Sci. 2014, 69, 245-252. [CrossRef] [PubMed]

77. Rivron, N.C.; Raiss, C.C.; Liu, J.; Nandakumar, A.; Sticht, C.; Gretz, N.; Truckenmüller, R.; Rouwkema, J.; van Blitterswijk, C.A. Sonic hedgehog-activated engineered blood vessels enhance bone tissue formation. Proc. Natl. Acad. Sci. USA 2012, 109, 4413-4418. [CrossRef] [PubMed]

78. Bergmann, O.; Zdunek, S.; Felker, A.; Salehpour, M.; Alkass, K.; Bernard, S.; Sjostrom, S.L.; Szewczykowska, M.; Jackowska, T.; Dos Remedios, C.; et al. Dynamics of cell generation and turnover in the human heart. Cell 2015, 161, 1566-1575. [CrossRef] [PubMed]

79. Pinto, A.R.; Ilinykh, A.; Ivey, M.J.; Kuwabara, J.T.; D’Antoni, M.L.; Debuque, R.; Chandran, A.; Wang, L.; Arora, K.; Rosenthal, N.A.; et al. Revisiting cardiac cellular composition. Circ. Res. 2016, 118, 400-409. [CrossRef] [PubMed]

80. Roncalli, J.; Renault, M.A.; Tongers, J.; Misener, S.; Thorne, T.; Kamide, C.; Jujo, K.; Tanaka, T.; Ii, M.; Klyachko, E.; et al. Sonic-hedgehog-induced functional recovery after myocardial infarction is enhanced by amd3100-mediated progenitor-cell mobilization. J. Am. Coll. Cardiol. 2011, 57, 2444-2452. [CrossRef] [PubMed]

81. Johnson, N.R.; Wang, Y. Controlled delivery of sonic hedgehog morphogen and its potential for cardiac repair. PLoS ONE 2013, 8, e63075. [CrossRef] [PubMed]

82. Rydén, L.; Grant, P.J.; Anker, S.D.; Berne, C.; Cosentino, F.; Danchin, N.; Deaton, C.; Escaned, J.; Hammes, H.-P.; Huikuri, H.; et al. Esc guidelines on diabetes, pre-diabetes and cardiovascular diseases developed in collaboration with the easdthe task force on diabetes, pre-diabetes and cardiovascular diseases of the european society of cardiology (esc) and developed in collaboration with the european association for the study of diabetes (easd). Eur. Heart J. 2013, 34, 3035-3087. [PubMed]

83. Shah, A.D.; Langenberg, C.; Rapsomaniki, E.; Denaxas, S.; Pujades-Rodriguez, M.; Gale, C.P.; Deanfield, J.; Smeeth, L.; Timmis, A.; Hemingway, H. Type 2 diabetes and incidence of cardiovascular diseases: A cohort study in 1.9 million people. Lancet. Diabetes Endocrinol. 2015, 3, 105-113. [CrossRef] 